\title{
Preface: the everyday politics of public space
}

Mattias De Backer, Claske Dijkema and Kathrin Hörschelmann

In: Space and Culture, 2019, DOI: 10.1177/1206331219830080

Pay attention to the inventive arenas that exert political power outside that stage or change the contents of the drama onstage. From the places that you have been instructed to ignore or rendered unable to see come the stories that change the world, and it is here that culture has the power to shape politics and ordinary people have the power to change the world. You can see the baffled, upset faces of the actors on stage when the streets become a stage. Solnit (2016: 26)

Over the last two decades or so, a rich literature has emerged about the politics of public space, including Iveson's (2013) work on the appropriation of public spaces by active/activist citizens involved in 'DIY urbanism, Hou's (2010) work on guerrilla urbanism, Holston's (2008) research on practices of everyday resistance and insurgent citizenship and Isin's (2008) and Massey et al.'s (2000) interventions on claiming rights to the city. Others, such as Mitchell (2003) and Low and Smith (2006), have considered public space's potential as a locus for (counter-)politics and activism, drawing on Lefebvre's trialectics.

At the same time, numerous critics have warned about the consequences of increasing surveillance, commercialisation, privatisation, militarisation and the sanitisation of public space (Atkinson, 2003; zukin, 1998; Lofland, 1998; Low 2001; Sorkin, 1992; Zukin, 2000), which limit possibilities for political expression in public space (publicity in space) and citizenship. These different forms of control over public space stand in tense relationship with the democratic ideal of a space that is open to all, acknowledged by all and in the interests of all (Carr et al., 1994; Henaff and Strong, 2001: 35, Sennett 1998; 2006; 2010). While Hou (2010: 3 ) is still optimistic that citizens can hold the state accountable through opportunities of assembly and public discourses, i.e. political expressions in public space, , Holston finds that erosions of citizenship come with the increased urge of the state to control public spheres, leaving no place for conflict (Holston, 1999; 2009).

However, many urban theorists, when talking about politics, refer to those phenomena of political participation that involve representative and deliberative systems, including "new forms of social organization-transnational labor organizing, indigenous rights and environmental justice movements (...)[which] are always creating alternative new spaces of and for public political expression" (Low and Smith, 2006: 16). In this special issue, we want to zoom in on the everyday and the micro-level as a site of political expression. For this we turn to the lens of performative, prefigurative and affective politics of the everyday, agreeing with Himada and Manning (2009: 5) that "Politics" with a capital ' $\mathrm{P}$ ' is much less the "real deal" than it presents itself. While "Politics" 
operates in the sphere of representation, where precomposed bodies are already circulating, "the micropolitical is that which subverts this tendency in the political to present itself as already formed."

Interestingly, as Brighenti (2008) notes, political philosophical reflection on the public sphere, such as that of Jurgen Habermas or Hannah Arendt, is almost exclusively focused on the dimension of political participation and deliberative procedures, while micro-sociological, interactionist studies of the public realm are mainly concerned with the cognitive frameworks and registers of interpersonal interaction. Both approaches, the author argues, "miss the spatial and material constraints that constitute the public" (p. 12). In tying these two interests together, we ask how micro- and everyday politics unfold along contested lines of publicness and privacy and whether conceptions of shared space need to be rethought when they are compared and contrasted with different articulations in diverse socio-cultural contexts and from intersectional perspectives. Empirical micro-sociological studies indicate how publicness and privacy are negotiated through embodied spatial practices, discursive constructions and the negotiation of access to public space, in relation to questions of visibility/invisibility, intimacy, fear, freedom, belonging, exposure, and recognition. This inevitably leads to a critical discussion of the central assumptions regarding private/public space and its generational, gendered, classed and 'culturalised' construction.

Beyond the revolutionary images of people claiming their rights during mass demonstrations at Tahrir Square, Maidan, Gezi Park, and an occupied Wall Street, we are interested in everyday appropriations of public space by marginalized groups and the ways in which they claim spaces of intimacy, privacy and freedom, while seeking to shape the city to their needs. The spatiality of intimacy versus exposure, of visibility versus invisibility, and of recognition versus misrecognition puts an emphasis on the different ways in which spaces are experienced by individuals and groups. For instance, research in Palestine has demonstrated that the much cherished European ideal of open and shared public spaces contrasts with the practices of women who want to traverse public space in a more concealed fashion (Abbas and van Heur, 2013).

However, visibility also exposes individuals to risks that a focus on the importance of claiming public space and gaining notable presence perhaps leads us to underestimate. Further, the value of public space may, for some, consist exactly in the opportunities that it offers for becoming less visible and for escaping restrictions that may be experienced in domestic spaces (Wilson 1992). Anonymity has been prized by many urban theorists as an urban characteristic that can provide freedoms not afforded by close-knit social contexts, where surveillance can be seemingly omnipresent (Wirth 1938, Benjamin 1935/1999). The boundaries between visibility and invisibility are thus frequently blurred and neither is unproblematic nor do they furnish a progressive politics per se, as 
gendered constructions and experiences of in/visibility in particular show. As De Backer argues in this issue, visibility and invisibility can "easily transform into the other or present themselves simultaneously" (cf. De Backer, 2018: 1). Visibility in itself is also far from unproblematic as a claim to urban citizenship. It can become a ground for contesting the presence of subaltern groups in public space and is not guaranteed to translate into achieving citizen rights to the city (cf. Dijkema, 2018, also see Hörschelmann and van Blerk, 2011).

This perspective on the micro and everyday can be understood against the backdrop of several theoretical axes: Katz's notion of minor theory $(1995,1996$, 2017), the work of Foucault, de Certeau and Lefebvre on the production of power, knowledge and place, and prefigurative spatial politics in anarchist theory.

1) Cindy Katz' notion of minor theory is a first cornerstone bringing together empirical work on everyday politics of public space. She argues that the 'cultural turn' sparked an interest in those subaltern groups excluded from knowledge production. However, the rules of the game of knowledge production have remained the same, which makes it nearly impossible to dismantle it and rebuild an alternative. Instead of continuing to focus on the absences, exclusions and silences, the author develops a conceptual framework to alter the ways knowledge is produced and shared. Instead of describing oppression in the lexicon of major theory, she advocates for the development of minor theory:

The differences are about performance; different ways of 'doing theory', different ways of reading, writing, is spitalking that apparently remain veiled to those still bent on 'mastery'. Maybe these practices are not so much veiled as unappetizing. They assert differences that are relentlessly material-embodied, positioned, sensual-that do not ignore the alternative material conditons (sic) under which knowledge is produced and shared. (Katz, 1996: 488)

Intriguingly, she adds that constituting the minor is about consciously working in a vocabulary in which one is not at home, in the analogy of the Czech writer Franz Kafka struggling with German while writing masterpieces such as Metamorphosis. It refers to the process of writing a minor literature by subverting a major language from within, forcing it to express something different. It is in this capacity that the minor is transformative, reworking the major from within: "[b]ecoming minor sets up an imbricated or interstitial politics; a way of negotiating and reworking a space of betweenness to produce something new" (p. 496).

2) This new space of knowledge refers strongly to the novel social and spatial realm which Henri Lefebvre (1991) called 'representational space'. Relevant as a theoretical backdrop for this special issue is the idea in Lefebvre's trialectics that the traditional opposition between the common and the powerful, or between routine navigations of space and top-down planning procedures, can be overcome in a thirdspace where true representation can occur, akin to a politics of 
contestation without a capital P. This is in line with Foucault's (1989) conceptualisations of the microphysics of power and with de Certeau's (1984) twin concept of 'strategy' vs. 'tactic'. Essential in the latter's analysis is the idea that being powerful or powerless is inextricably linked to the occupation of space. While the powerful can claim a permanent ownership over the central territories of our world-be it a medieval castle or the Chrysler Building — the powerless can only poach on this space (Fielder, 2001), claiming it temporarily in an act of defiance, protest and resistance. As illuminating as this double metaphor is, what is missing from de Certeau's analysis is the subtle in-betweenness and trialectics essential to authors such as Lefebvre and Deleuze, where the oppressed, while temporarily claiming a space for themselves, can simultaneously be the powerful, excluding others from their territory.

3) These struggles for power and knowledge do not only take place in space, they are of space. Space has political potential in the sense that it is in perpetual development: it cannot be separated from time (Massey, 1993). The present therefore holds the promise of the future and this promise is (pre)figured in space. As Ince (2012, p. 9) argues: "if territory is constituted and reconstituted over time, there is scope for intervention." This idea of openness and possibility does not foreclose the importance and political potential of boundary-making. The political nature of space resides notably in related bordering practices. Bordering refers to "the spatial strategic representation of the making and claiming of difference" (Berg and Van Houtum 2003:2 in Ince 2012, p.6). It is a tool of territorialisation, which Ince understands as "ongoing, uneven and contested processes associated with a range of powerful forces and constituted by diverse territorial practices infused with multiple political, cultural, economic and social trajectories and intersections" (cf. Marston 2000; Valentine 2007 in Ince 2012, p. 5-6).

Anarchist theory calls attention to the role that the bounding of spaces can play in the everyday "constitution and mobilization of political subjectivities and identities" which are "located in particular places, demarcating certain physical or symbolic territories" (Ince, 2012, 1650). The bounding of space plays an important role in prefigurative politics. Prefiguration refers to a beginning, a start of something that will be continued in the future and will shape the contours of this future. The creation of new forms of boundaries which are formed independently or in interaction with those imposed through territorial governance thus have the function to protect the self but also to build anew and enter in relation. Beyond protection, they thus create possibilities to speak out, to formulate political statements through translating/transforming everyday practice and individual opinions into collective discourse.

Inspired by these three theoretical axes, this special issue begs the question of what can be considered political in the public realm. The everyday uses of public space that this special issue deals with, have in common that they take as a starting 
point those at the lower end of asymmetric power relations: young girls/men (Wijntuin and Koster); racialised youth in marginalised social-housing neighbourhoods (De Backer, Dijkema); children in cities dominated by cars (Caroll et al.); and finally those speaking minority languages (Polese et al.). On what basis can we qualify these groups' behaviour as political?

Much ink has been spilled on the question "what is political?" and where to draw the line between the political and the apolitical: the 'not-quite political' (as in politics with a capital ' $\mathrm{P}$ '), the pre-political (Mauger, 2006), the proto-political or infrapolitical (Scott 1985, 1990, 2012) and the postpolitical (Wilson and Swyngedouw, 2014). However, not all authors agree on their definition of the political. Rancière argues that "political activity makes visible what had no business being seen, and makes heard a discourse where once there was only place for noise" (Rancière, 1999, p. 30; translation modified in Dikeç 2012, p. 674). Politics implies "the refusal of an identity imposed by others" (Davis, 2010: 88). It has to be understood not as a goal to be reached in the future but as an "open set of practices driven by the assumption of equality between any and every speaking being and by the concern to test this equality" (Rancière, 1999: 30). An act functions politically if, through it, 'those that have no part' achieve to be taken into account. To those authors, the political is disruptive (Dikeç, 2017) and consists of an antagonistic moment (Dikeç, 2012, p. 674).

Others have argued that this definition of what constitutes politics is too narrow (Beveridge and Koch 2017). In their critique of the post-political city, which draws attention to the depoliticization of cities, they insist on the contingency between politicisation and depoliticization and on political agency beyond the antagonistic moment. This is closer to Scott's concept of infrapolitics (2012) which refers to a kind of politics that avoids direct confrontation but opens up to a "subterranean world of political conflict". His analysis is limited to contexts in which direct confrontation would be too costly and in which direct claims of those at the lower end would not be heard. For Scott, the political lies in the accumulation of everyday acts - and not in the individual acts themselves - that, together, can have a massive effect. Solnit (2016), in her passionate analysis of activism, refers to the importance of hope, imagination and determination of ordinary people in the shadows, long before a movement is formed and becomes recognised as political.

Where Beveridge and Koch's conception of the political differs though, is in the function of visibility of conflict as a condition for the political (2017). Papers in this issue claim that tactics of invisibility may just as much be a part of the political as those tactics of visibility more often researched (De Backer; Wijntuin and Koster this issue). Rather than deciding on one specific definition of the (a)political, we argue with Beveridge and Koch (2017, p. 10) that "drawing the boundary between the two is an integral part of (de)politicization and the 
normative and institutional ordering of politics which emerges from it." If we want urban research to be a rampart against depoliticisation and contribute to equal access to city spaces we need to make an effort to recognize the political beyond the antagonistic moment and beyond visibility (Davidson and Iveson 2014).

The papers in this special issue are empirical studies into agency in public space by those who claim their part in the city through disobeying norms that may be patriarchal (Wijntuin and Koster this issue); racist (Dijkema, this issue) or intersectional (De Backer, this issue) in nature; or by those whose access to public space is limited as a result of the priority given to cars (Caroll et al., this issue) or-in a more symbolic sense-through the imposition of language (Polese et al. this issue). The city hereby is not a stage for political action, for making a claim, but access to the city itself is the claim.

\section{Contributions}

The special issue brings together work that elaborates these theoretical concerns about the significance of everyday negotiations of, and micro-political challenges to, public/private space divides further through contextualised readings and analyses of diverse case studies. To prepare the special issue, we asked our contributors to reflect on the following questions:

- How are publicness and privateness produced performatively?

- How can embodied and affective interaction between people and place also be political?

- How does this construct as well as problematize public/private space and the divides between them? And what role does (in)visibility play here?

- How should we reformulate insights about the political function of public space gained by authors such as Mitchell (2003) or Low and Smith (2006), when we include the 'politicalness' of everyday interaction, especially taking into account the gendered, generational, culturalised and classed nature of public space?

- In which cases can claims to space be interpreted as a form of prefigurative politics? Can Schatzki's idea of prefigurative politics helps us to further extend our understanding of public space beyond Enlightenment ideals of the public sphere as a space for deliberation and active citizenship?

- How do radical approaches to public space respond to diverse articulations and performances of publicness and privacy?

In their contribution to this special issue, Penelope Carroll, Octavia Calder-Dawe and Karen Witten answer these questions through an analysis of data on children's practices of play, collected in nine inner city and suburban neighbourhoods in Auckland, New Zealand. They identify some interesting contradictions in how we, as a society and as adults, approach and "territorialise" 
children. For instance, since the UN Convention on the Rights of Children (1989), children's rights to protection have been acknowledged to a much greater extent than their rights to agency and self-realisation. Similarly, children have increasingly been given a formal role in politics, through youth parliaments, councils and advisory groups, but their being political actors in everyday practices has not received the same recognition. These everyday practices are at the heart of Carroll et al.'s paper, in which they analyse their children's behaviour as political, prefiguring a desired future including new forms of sociality and a fairer, more child-friendly and playful city. While adult citizen-activist initiatives can generally be considered overt examples of prefigurative politics, children's play is much subtler; it is experimental and experiential rather than deliberate and goaloriented, it prefers doing over saying and feeling over reasoning.

Polese deals with contestations in and over public space, including institutions such as public schools. He is interested in "actors of a country" that negotiate and compete over its regulation. The author explores everyday resistance to state policy through informal practices, namely the choice of speaking a language other than that sanctioned by the state. The empirical evidence comes from the city of Odessa, where Russian is the primary language for a large part of the population while Ukrainian is the official language. When public servants (teachers) discuss non-work related themes in Russian they, in some ways, bring into the public a language that is supposed to remain in the private sphere. They play with the distinction between private and public spaces. For example, while courses will take place in Ukrainian, informal exchanges between teachers and pupils or between colleagues in public schools may take place in Ukrainian, thereby trespassing state law and carving out a space in public for what are supposed to be private practices. Through speaking Russian, they de facto "minimize state influence in a given situation" (Polese 2018, p.3). This form of political action is based on a Foucauldian conceptualization of power as diffuse, present everywhere, embodied in discourses and knowledge, and which transcends politics with a capital P (Polese 2018, p.4), allowing observation of subaltern responses to power.

Claske Dijkema and Mattias de Backer both consider how young people from marginalized ethnic communities contest racism, control and exclusion from urban citizenship through micro-political practices of becoming in/visible. Claske Dijkema asks whether such micro-political practices of claiming space and of developing noticeable presence in marginalized urban spaces, which are qualified as uncivil behaviour by those in charge of public order, can be understood as claims to citizenship. Her paper attends to the ways in which citizenship is negotiated through localized practices and everyday forms of confrontation in postcolonial France. Analysing both the sites and the acts through which racialized young men in a social housing estate in Grenoble exercise 'insurgent citizenship', she comes to the conclusion that their localised claims to space qua visibility don't 
address a wider public and therefore can only be partially understood as claims of citizenship. Access to public space is the claim.

Mattias de Backer examines similar practices of negotiating in/visibility in the city. He focuses particularly on the ways in which young men and women from migrant communities in Brussels deal with the paradoxical relationship between visibility as control (surveillance) and visibility as recognition/a way of claiming citizenship through access to public space. He attends to the role of gender in the different negotiations of in/visibility in private and public space, while also drawing attention to transgression as a way of staking belonging to the city. De Backer's analysis brings to light the potential of transforming public space by playing with visibility and invisibility, such as when young men intentionally occupy hypersurveilled spaces in central parts of the city and contest the exclusions that such surveillance might otherwise institute. He concludes that regimes of visibility, which include ambient features and material structures, can easily transform into each other and that public space is changed through practices of playing with in/visibility in turn.

Echoing several observations of De Backer's analysis, Wijntuin and Koster present findings from research undertaken in Utrecht, The Netherlands. They find that young men and women of Moroccan origin follow remarkably different spatial patterns: the former are stationary and claim a space while hanging out, while the latter wander around. However, this more fleeting use of space also enables them to claim it, but in a radically different manner. Wandering is considered as a legitimate way for girls to be outside, it enables them to escape social control inside and outside the house and it make it possible for these girls to interact with boys in a way that is both socially acceptable and negotiates the norm. Interestingly, while De Backer sheds light on the practices of these young men, using tactics against dominant control infrastructures while dominating female behaviour in their home neighbourhoods from a position of power, Wijntuin and Koster analyse the young women's behaviour as combining strategic (intentional) and tactical (improvisational) navigation.

Wijntuin and Koster point at the notion of "resistance", used by studies such as that of Peleman (2003) and Ehrkamp (2013), to analyse subaltern groups' practices in public space, with female teens of North-African origin depicted as agents who purposefully or unintentionally resist the male spatial dominance. This binary logic of domination and resistance has been criticised by feminist Muslim scholars (Abu-Lughod 1985; Ahmed, 1992; Bilge, 2010; Bracke and Fadil, 2012; Ilahi, 2009) who convincingly show that such a western perspective on gender and feminism does not hold in other regions. This subtler power relation between men and women in the East is mirrored by more complex distinctions of public and private (Mazumdar and Marumdar, 2001; Mohammad, 2013). 
Perhaps not everything that is part of the sidewalk ballet is necessarily a prelude to a political movement or a revolution, but many visible and invisible minor acts are part of a power negotiation that has political value. If we can continue to work on the necessary language to describe it, not only will our understanding grow, it will also contribute to developing a vocabulary that enables change. Moreover, developing a new language can also serve as an impetus to unlock the implicit knowledge which Foucault called savoir, holding a mirror to the academic world:

In a society, different bodies of learning, philosophical ideas, everyday opinions, but also institutions, commercial practices and police activities, mores - all refer to a certain implicit knowledge [savoir] special to this society. This knowledge is profoundly different from the bodies of learning [des connaisances] that one can find in scientific books, philosophical theories, and religious justifications." (Foucault, 1998: 261).

In order to tap into this practical wisdom, we think, it is necessary to consider both grand political theory and a sharp eye for the micro-sociology of the public realm, for the routine navigation of bodily movement, the negotiation of identity and the coping with the ever-present conflicts which Soenen (2006) has so aptly called "the small encounter." 


\section{References:}

Abbas, M. and van Heur, B. (2013), Thinking Arab women's spatiality: the case of 'mutanazahat' in Nablus, Palestine. Gender, Place \& Culture: A Journal of Feminist Geography. https://doi.org/10.1080/0966369X.2013.817969

Abu-Lughod, L. (1985). A community of secrets: The separate world of Bedouin women. Signs: Journal of Women in Culture and Society, 10(4), 637-657.

Ahmed, L. (1992), Women and gender in Islam. New Haven \& London: Yale University Press.

Benjamin, Walter, (1935/1999). The return of the flâneur. Selected Writings 2, Cambridge, MA: Harvard University Press, 1927-1943.

Beveridge, R., Koch, P., (2017). The post-political trap? Reflections on politics, agency and the city. Urban Studies 54, 31-43. https://doi.org/10.1177/0042098016671477

Bilge, S. (2010). Beyond subordination vs. resistance: An intersectional approach to the agency of veiled Muslim women. Journal of intercultural studies, 31(1), 9-28.

Davidson, M. and Iveson, K., (2014). Recovering the politics of the city: From the 'post-political city' to a 'method of equality' for critical urban geography. Progress in Human Geography. https://doi.org/10.1177/0309132514535284

Davis, M. (1992), Fortress Los Angeles: the militarization of urban space. In M. Sorkin (ed.), Variations on a theme park: the new American city and the end of public space. New York: Noonday Press, 154-180.

de Certeau, M. (1984), The practice of everyday life (trans. S.F. Rendall). Berkeley: California University Press.

Dikeç, M. (2012). Space as a mode of political thinking. Geoforum, Elsevier. Retrieved from https://hal-enpc.archives-ouvertes.fr/hal-01274396

Dikeç, M., (2017). Disruptive politics. Urban Studies 54, 49-54. https://doi.org/10.1177/0042098016671476

Ehrkamp, P. (2013). 'I've had it with them!' Younger migrant women's spatial practices of conformity and resistance. Gender, Place \& Culture, 20(1), 19-36.

Fielder, A. (2001), Poaching on public space: urban autonomous zones in French Banlieue Films. In: M. Shiel \& T. Fitzmaurice (eds.), Cinema and the city. Film and urban societies in a global context. Oxford: Blackwell Publishers.

Foucault, M. (1989), Discipline, toezicht en straf. Groningen: Historische Uitgeverij Groningen.

Lefebvre, H. (1991) [1974], The production of space. (trans. D. Nicholson-Smith). Oxford: Blackwell Publishing.

Lofland, L.H. (1998), The public realm: exploring the city's quintessential social territory. New Brunswick and London: Aldine Transaction.

Low, S. and Smith, N. (eds.) (2006), The politics of public space. London \& New York: Routledge.

Himada N and Manning E (2009) From noun to verb: The micropolitics of making 
collective. Inflexions: A Journal for Research Creation, 3: 1-17.

Katz, C. (1995), Major/minor: Theory, nature, and politics. Annals of the Association of American Geographers 85(1): 164-168.

Katz C (1996) Towards minor theory. Environment and Planning D: Society and Space, 14: 487-499.

Katz, C. (2017), Revisiting minor theory, Environment and Planning D: Society and Space, 35(4): 596-599.

Mauger, G. (2006). L'émeute de novembre 2005: une révolte protopolitique (l'association Raisons d'agir). Bellecombe-en-Bauges: Édition du Croquant.

Mazumdar, S., \& Mazumdar, S. (2001). Rethinking public and private space: Religion and women in Muslim society. Journal of Architectural and Planning Research, 302-324.

Mitchell, D. (2003), The right to the city. Social justice and the fight for public space. New York \& London: The Guilford Press.

Mohammad, R. (2013). Making gender, ma(r)king place: Youthful British Pakistani Muslim women's narratives of urban space. Environment and Planning A, 45(8), 1802-1822.

Peleman, K. (2003). Power and territoriality: A study of Moroccan women in Antwerp. Tijdschrift voor economische en sociale geografie, 94 (2), 151-163.

Scott, J.C., (1990), Domination and the Arts of Resistance: Hidden Transcripts, New aven: Yale University Press.

Scott, J.C., (2000 [1985]). Weapons of the weak: everyday forms of peasant resistance, Nachdr. ed. Yale Univ. Press, New Haven.

Scott, J.C., (2012). Infrapolitics and Mobilizations: A Response by James C. Scott. Revue française d'études américaines 112-117. https://doi.org/10.3917/rfea.131.0112

Solnit, R. (2016), Hope in the dark: untold histories, wild possibilities. Edinburgh \& London: Canongate.

Rancière, Jacques, (1999). In: Rose, J. (Ed.), Disagreement: Politics and Philosophy. Minneapolis: University of Minnesota Press.

Wilson, Elizabeth, (1992). The sphinx in the city: Urban life, the control of disorder, and women. Berkeley and Los Angeles: University of California Press.

Wilson, J., Swyngedouw, E. (Eds.), (2014). The Post-Political and its Discontents: Spaces of Depoliticisation, Spectres of Radical Politics. Edinburgh University Press.

Wirth, Louis, (1938). Urbanism as a Way of Life. American Journal of Sociology, 44 (1), 1-24. 